\title{
Teach Them How to Fish, Help Them to Survive: Empowering Future Doctors in Nigeria through Work-Study Programmes
}

Submitted: $28-05-2020$

Accepted: 08-06-2020

Online: $30-12-2020$

\author{
Kehinde Kazeem Kanmodi ${ }^{1,2,3}$ \\ ${ }^{1}$ Cephas Health Research Initiative Inc, Ibadan, NIGERIA \\ ${ }^{2}$ Mental and Oral Health Development Organisation, Birnin Kebbi, \\ NIGERIA \\ ${ }^{3}$ Department of Community Health, Aminu Musa Habib College of \\ Health Science and Technology, Yauri, NIGERIA
}

To cite this article: Kanmodi KK. Teach them how to fish, help them to survive: empowering future doctors in Nigeria through work-study programmes. Education in Medicine Journal. 2020;12(4):17-23. https://doi.org/10.21315/eimj2020.12.4.3

To link to this article: https://doi.org/10.21315/eimj2020.12.4.3

\begin{abstract}
The work-study programme is a student-friendly and institution-friendly initiative that had been in legal existence for decades in the Western world. The benefits attached to work-study are enormous, some of which include acquisition of technical skills, research skills, administrative skills, leadership skills, increased financial income, and on-the-job experience, just to mention a few. However, in Nigerian tertiary schools, the work-study programme is yet to gain much foothold; many Nigerian students are not benefitting from school-created part-time job positions since many schools do not have such programmes in place. Although some Nigerian tertiary schools had embraced and as well created work-study programmes for students in this recent decade; however, the programme is still premature in such schools because not all of students are equally benefitting from that programmes. The medical and dental students especially those in the clinical phase of academic programmes are yet to benefit from such programmes due to the unfavourable structure of academic programmes and other factors. Hence, this article is to emphasise on the need for the creation of doable work-study opportunities for medical and students in Nigeria.
\end{abstract}

Keywords: Work-study, Programme, Medical, Dental, Nigeria

Dr. Kehinde Kazeem Kanmodi, Cephas Health Research Initiative Inc, Ibadan, Nigeria Email: kanmodikehinde@yahoo.com

\section{INTRODUCTION}

By way of definition, "work-study" is a concept that is used to describe a situation in which you work for only some of the day or the week and also go to school (1). Historically, the work-study concept was first recognised by the United States (US) government and translated into a programme on 20 August 1964, when it established the Economic Opportunity Act of 1964 with the purpose of mobilising human and financial resources of the country to fight poverty amongst its populace (2). It was through this act that the federal work-study programme was born in the US, officially. By this programme, many students from low-income families were 
able to secure part-time employment in the institutions where they are studying (3). So far, many other Western nations had also developed similar programmes to cater for the needs of their poor students $(4,5)$.

Many countries had developed/modified the two main teaching-learning approaches (traditional teaching-learning approach, and the open and distance teachinglearning approach) in a way that it is student-friendly through the provision of work-study opportunities for their enrollees (4-9). The traditional approach requires students to be physically present in classrooms to participate in teachinglearning processes and it is primarily practiced in the traditional tertiary schools (4-9). As a means of providing workstudy opportunities for students enrolling in traditional tertiary schools, concerned schools either enroll admitted students for full-time academic programmes with offers of part-time employments or enroll them on part-time for giving the opportunity to work full-time at their respective work places and not necessarily the school where they are enrolled (1-9). Meanwhile, on the other hand, the open and distance teachinglearning approach is practiced by open tertiary schools. Usually, these schools enroll online students and provide them to study their academic programme at their own pace while they continue in their jobs (4-9). However, many traditional tertiary schools had started the utilisation of open and distance teaching-learning approach to train their students $(6,7)$.

In light of the above, the aims of this article are to give an overview on work-study programme in Nigeria in comparison with what applies in the Western world, the benefits associated with such programme and a recommendation for the creation of programmes in all medical and dental schools in Nigeria.

\section{BENEFITS AND PITFALLS OF WORK- STUDY: OVERVIEW}

There are many benefits associated with work-study. Some of these benefits include financial buoyancy, work experience, emotional stability, acquisition of technical skills, and more (10-13). However, as there are many benefits attached to workstudy, there are also some risks attached, if it is not practiced cautiously. According to the research report, it was observed that students who spent too much time on parttime jobs at the expense of their study do suffer from poor academic performance (14). Hence, this showed that work-study can be a counter-productive if not done cautiously.

\section{WORK-STUDY PROGRAMME IN NIGERIA: THE CURRENT PICTURE}

In a recent report released by the Ministry of Labour of the Federal Republic of Nigeria, there is no clear national policy in favour of work-study among students in the traditional tertiary institutions (15). However, the only available opportunity created by the federal government to "work" as a tertiary school student in Nigeria was the Students' Industrial Work Experience Scheme (SIWES) programme and this opportunity is limited and not really a workstudy programme per se $(15,16)$. In actual sense, the SIWES programme is not a workstudy programme because:

(a) SIWES is an academic programme;

(b) a significant proportion of students that participated in the SIWES programme did not benefit from stipends, to the best of author's knowledge;

(c) the SIWES programme was established primarily for skills acquisition with a little financial benefits (in the form of stipends) given to participating students; 
(d) not all students are beneficiary from the SIWES programme because not all of them have SIWES participation in their academic curriculum; such as medical and dental, nursing and physiotherapy students (15-18).

However, probably due to the deficiency in the Nigeria policy, only a few institutions in Nigeria (such as Covenant University, Obafemi Awolowo University and University of Ibadan) had officially created work-study programmes for needy students (19-22). This programme is relatively new in the Nigerian university system and it is yet to be universally adopted by many universities in Nigeria probably due to existing national policy gaps, limited funds and competing priorities (19-22). Furthermore, the author of this study would like to discuss more about the workstudy programme in the University of Ibadan because of the following reasons such as University of Ibadan is the home to the oldest and largest College of Medicine in Nigeria; the author obtained his dental degree from this university and he had also led a scientific research activity which explored the school's workstudy programme while studying at the university's dental school from 2010 to 2016 (22). Based on author's observation, the departmental distribution of the beneficiaries of the University of Ibadan's work-study programme is skewed; only a little or none of the beneficiaries of the school's work-study programme are dental or medical students. This is because the work-study programme office is not situated within the college of medicine area. Furthermore, the work-study programme is not incorporated with the educational structure and system of the university's medical and dental programme.

\section{STRUCTURE OF MEDICAL AND DENTAL DEGREE PROGRAMME IN NIGERIA}

The medical (MBBS; MBChB) and dental (BDS; BChD) degree programmes in Nigeria are traditionally having six years duration, exclusively full-time, and they are strictly awarded by universities $(17,22$, 23). Generally, the first two-and-half to three years is the pre-clinical phase while the last three-and-half to four years is the clinical phase of the programme. The preclinical phase runs in a semester system like the other university bachelor degree programmes. Meanwhile, the clinical phase runs in an entirely different manner; in this phase the programmes runs yearly without semester break $(17,22,23)$. The only break that these students enjoy are periods of: compulsory stay-at-home order due to epidemic outbreaks, industrial strikes by lecturers and relevant hospital staff, and during exam scripts are being marked and students are awaiting exam results (usually few days to one week). Hence, the medical and dental students in the clinical phase of degree programme are always spend their time at school, learning year-round $(17,22$, 23).

\section{THE FOREIGN PICTURE: WORK- STUDY OPPORTUNITIES AMONG CLINICAL STUDENTS IN US AND UK}

In the US and some European countries (such as New Zealand, Netherlands and UK), work-study programme is an opportunity incorporated into their clinical training programmes (24-29). These students assume the positions of paid assistantships, etc. Through these positions, many of them were able to acquire some stipends/wages; sense of responsibility; clinical, leadership, research and laboratory skills (24-29). 


\section{ATTITUDES OF CLINICAL STUDENTS TOWARDS WORK-STUDY: NIGERIAN EXPERIENCE}

Only very limited scientific evidence is available on the attitudes of medical and dental students in Nigeria (22). However, the available study on this area showed that majority of a surveyed sample of clinical students (medical and perhaps, dental students as well) were positively disposed towards participating in workstudy programmes (22). About $91.7 \%$ of them were willing to work as a research assistant, laboratory assistant, radiology technician, pathology demonstrator and surgical assistant (22). Importantly, majority $(55.6 \%)$ of them are not studying on scholarship; hence, they largely depend on their families to survive (22). Interestingly, not all of the surveyed clinical students wanted to participate in a workstudy programme just because of moneymaking purposes; rather, many of them participate in such programme because they acquire technical skills and learn through mentorship (22).

\section{BENEFITS OF WORK-STUDY PROGRAMME IN NIGERIA: FOCUS ON MEDICAL AND DENTAL EDUCATION}

The work-study programme had several benefits and it is not a wonder that workstudy programmes had been in legal existence in the Western world for decades (1, 24-29). The sub-Saharan African countries, especially Nigeria, should consider such programmes for the benefits of their academic and labour systems (1922). In a study conducted by Isiekwe et al. (23) found that the dental school curriculum in Nigeria has a pitfall, which was lack of business management-related course in the entire dental school curriculum of the Nigerian dental schools. Besides that, the study also identified the course did not give the opportunity to the Nigerian-trained dentists to have adequate managerial skills needed to set up and run a private dental practice. However, same situation applies to the medical students as well; as such, course is not a part of medical school curriculum of many, if not all, Nigerian schools (17). However, through the adoption of the use of work-study programmes, many medical and dental students in Nigeria can acquire business management skills through their participation in such programmes $(16,18)$.

Similarly, there was a recent report that many Nigerian-trained doctors had never received any training on leadership skill acquisition since they have started clinical practice (30). This poses a serious problem to the future of Nigerian-trained doctors as regard clinical practice and other managerial/leadership practices.

Furthermore, the Nigerian healthcare system especially at the tertiary hospitals is highly understaffed $(31,32)$. A few employed personnel in the Nigerian hospitals are over-burdened with heavy workloads, which caused a problem that spreads across the departments in the hospital (including clinical, research and laboratory). As a matter of common sense, there are some clinical, laboratory or research procedures/tasks that can be done by a medical or dental student, independently or under supervision of a supervisor. Through the official engagement of medical and dental students with paid part-time job positions, the heavy workload in various departments (including clinical, research and laboratory) of various teaching hospitals in Nigeria will be eased.

\section{CALL FOR THE CREATION OF WORK- STUDY PROGRAMMES IN DENTAL AND MEDICAL SCHOOLS IN NIGERIA}

Over $50 \%$ of Nigerians are living in extreme poverty (33), the population of which may include the households of poor medical and dental students in Nigeria. In fact, due to the heavy financial implications 
of studying medical or dental in Nigeria, many poor students do suffer from burnout while some ended up by dropping out from their study programme due to lack of funds (34). Nigeria is a country with very high doctor-population ratio, making many Nigerians highly underserved (32). With the relative scarcity of doctors coupled with the rising poverty rate in Nigeria $(32,33)$, it is reasonable for the government to take drastic steps that will reduce the rates of burnout and drop out in medical and dental schools in Nigeria.

There is an urgent need for the Federal Government of Nigeria to review the existing policies on undergraduate medical and dental education to favour the inclusion of work-study programmes into the medical and dental education system in Nigeria. Not just stopping at policy creation level, the government should also direct and empower all medical and dental schools towards the implementation of work-study programmes through the provision of all resources that are needed.

\section{CONCLUSION}

The inclusion of work-study programmes into undergraduate medical and dental education system and structure is a very laudable initiative that will reap rewards to all stakeholders concerned. Hence, the creation and implementation of educational and labour policies in favour of the adoption of this laudable initiative in Nigeria medical and dental schools should be gladly embraced.

\section{REFERENCES}

1. Cambridge Dictionary. Work-study. c2020 [cited 2020 May 24]. Available from: https://dictionary.cambridge.org/dictionary/ english/work-study
2. Campus Compact. A brief history of the federal work-study program. 2019 January 18 [cited 2020 May 24]. Available from: https://compact.org/initiatives/federal-workstudy/brief-history/

3. De Anda MA. The impact of the federal work-study program on firstgeneration college students of color [dissertation]. California: San Francisco State University; 2018 [cited 2020 May 24]. Available from: http://dspace.calstate. edu/bitstream/handle/10211.3/203876/ AS362018EDUCD43.pdf?sequence $=1$

4. Higher Education Compass. Dual programmes - studying and work experience. n.d. [cited 2020 May 24]. Available from: https:/www. hochschulkompass.de/en/degreeprogrammes/all-about-studying-ingermany/forms-of-study/dual-work-studyprogrammes.html

5. Studyinbelgium.be. Working during your studies. n.d. [cited 2020 May 25]. Available from: http://www.studyinbelgium.be/en/ content/working

6. Ouma R, Nkuyubwatsi B. Transforming university learner support in open and distance education: staff and students perceived challenges and prospects. Cogent Educ. 2019;6(1). https://doi.org/10.1080/23 31186X.2019.1658934

7. Patru M, Khvilon E. Open and distance learning: trends, policy and strategy considerations. Paris: UNESCO; 2002.

8. Fooladvand M, Yarmohammadian MH. A comparative study between virtual and traditional approaches in higher education in Iran. Social and Behavioral Sciences. 2011;28:646-50. https://doi.org/10.1016/j. sbspro.2011.11.122

9. Tularam GA, Machisela P. Traditional vs non-traditional teaching and learning strategies - the case of e-learning! Int J Math Teach Learn. 2019;19(1):129-58. 
10. Vickers M, Lamb S, Hinkley J. Student workers in high school and beyond: the effects of part time employment on participation in education, training and work. 2003 [cited 2020 May 25]. Available from: http://research.acer.edu.au/lsay_ research/34

11. Manthei RJ, Gilmore A. The effect of paid employment on university students' lives. Education + Training. 2005;47(3):202-15. https://doi.org/10.1108/00400910510592248

12. Curtis S. Students' perception of the effects of term-time paid employment. Education + Training. 2007;49(5):380-90. https://doi. org/10.1108/00400910710762940

13. Biddle N. The labour market status of Australian students: who is unemployed, who is working, how many hours? J Educ Work. 2007;20(3):179-209. https://doi. org/10.1080/13639080701464467

14. Carney C, McNeish S, McColl J. The impact of part time employment on students' health and academic performance: a Scottish perspective. J Further High Educ. 2005;29(4):307-19. https://doi. org/10.1080/03098770500353300

15. Federal Ministry of Labour and Employment (Nigeria). National employment policy 2017. 2017 [cited 2020 May 26]. Available from: https:// www.labour.gov.ng/Doc/NATIONAL EMPLOYMENT_POLICY.pdf

16. Asikogu LO, Okopu NP. Students industrial work experience scheme (SIWES) in architecture: the need for appropriate job specification. AARCHES J. 2009;8(1):30-8.

17. College of Medicine, University of Ibadan. Prospectus 2006-2008. Nigeria: University of Ibadan; 2005.

18. National Open University of Nigeria. Students' industrial work experience scheme. c2019 [cited 2020 May 26]. Available from: https://nou.edu.ng/ directorates/students-industrial-workexperience-scheme-siwes
19. Omonijo DO, Oludayo AO, Uche OOC, Rotimi OA. Assessment of job assignments of work-study students, Convenant University, Ota, Southwest Nigeria. American Journal of Scientific Research. 2014;104(5):43-53.

20. Adewale TO, Ajayi NA. Student librarian work-study programmes in academic libraries: an appraisal. Library Philosophy and Practice. 2010;March. [cited 2020 May 26]. Available from: http://digitalcommons. unl.edu/libphilprac/336/

21. Oludayo AO, Omonijo DO, Uche OOC, Rotimi AO, Nwadialor KL. Evaluation of students work-study programme: the case of a private (faith-based) higher education institution, south-west, Nigeria. Journal of Education, Society and Behavioural Science. 2014;4(6):784-809. https://doi.org/10.9734/ BJESBS/2014/8397

22. Kanmodi KK, Akinloye AG, Aladelusi TO. Attitudes of medical students towards taking part-time jobs: a study amongst first year clinical students of the College of Medicine, University of Ibadan. Ann Ibd Postgrad Med. 2017;15(1):45-50.

23. Isiekwe GI, Sofola OO, Sanu OO, Oredugba FA. Undergraduate dental curriculum of a Nigerian dental school and the behavioural science and management skills required for private dental practice. J Den. Oral Hyg. 2013;5(5):40-4.

24. Braniff C, Spence RA, Stevenson M, Boohan $M$, Watson P. Assistantship improves medical students' perception of their preparedness for starting work. Med Teach. 2016;38(1):51-8. https://doi.org/10.3 109/0142159X.2015.1045843

25. Burford B, Ellis E, Williamson A, Forrest I, Vance G. Learning opportunities in "student assistantships". Clin Teach. 2015;12(3):222. https://doi.org/10.1111/tct.12269 
26. Crossley JG, Vivekananda-Schmidt P. Student assistantships: bridging the gap between student and doctor. Adv Med Educ Pract. 2015;6:447-57. https://doi. org/10.2147/AMEP.S62822

27. Griswold K, Silverstein D, Lenkei E, Fiedler R. Research skills for medical students: a summer assistantship in family medicine. Fam Med. 1991;23(4):306-7.

28. Park SJK, McGhee CNJ, Sherwin T. Medical students' attitudes towards research and a career in research: an Auckland, New Zealand study. N Z Med J. 2010;123(1323):34-42.

29. Poorterman JH, Dikkes BT, Brand HS. Dental hygiene students' part-time jobs in dental practices in the Netherlands. Int J Dent Hyg. 2010;8(2):143-6. https://doi. org/10.1111/j.1601-5037.2009.00415.x

30. Isibor E, Kanmodi K, Adebayo O, Olaopa O, Igbokwe M, Adufe I, et al. Exploring issues and challenges of leadership among early career doctors in Nigeria using a mixed-method approach: CHARTING study. Eur J Investig Health Psychol Educ. 2020;10(1):441-54. https://doi.org/10.3390/ ejihpe 10010033
31. World Health Organization, Global Health Workforce Alliance. Nigeria. c2020 [cited 2020 May 26]. Available from: https://www. who.int/workforcealliance/countries/nga/en/

32. Ogundipe S, Obinna C, Olawale G. Shortage of medical personnel: Tougher times ahead for Nigerians (1). Vanguard. 2015 January 27 [cited 2020 May 26]. Available from: https://www. vanguardngr.com/2015/01/shortage-medicalpersonnel-tougher-times-ahead-nigerians-1/

33. World Bank. Poverty and equity brief: subSaharan Africa, Nigeria. 2019 October [cited 2020 May 26]. Available from: https://databank.worldbank.org/data/ download/poverty/33EF03BB-9722-4AE2ABC7-AA2972D68AFE/FM2019/Global_ POVEQ_NGA.pdf

34. Egwu OA, Anyanwu GE. Five-year survey of medical student attrition in a medical school in Nigeria: a pilot study. Adv Med Educ Pract. 2010;1:53-7. https://doi.org/10.2147/ AMEP.S13395 